\title{
CHANGES IN NESTING DENSITY OF BALTIMORE ORIOLES (1976-1995) AND OTHER SPECIES IN THE DUNE-RIDGE FOREST, DELTA MARSH, MB: RESPONSE TO AN OUTBREAK OF FOREST TENT CATERPILLAR?
}

\author{
Spencer G. Sealy \\ Department of Biological Sciences \\ University of Manitoba \\ Winnipeg, MB R3T 2N2 \\ Spencer.Sealy@umanitoba.ca
}

For nearly a century, naturalists and ornithologists noted that Baltimore Orioles (Icterus galbula) and several other species of songbird nest at high densities in the riparian woodland that separates the southern basin of Lake Manitoba and Delta Marsh, Manitoba. ${ }^{1-4}$ In 1973, studies of habitat use and breeding ecology of these species were initiated in the dune-ridge forest. The dynamics of the Baltimore Oriole population became a focus three years later, the year that turned out to be the first year of an outbreak of Forest Tent Caterpillar (Malacosoma disstria Hbn.) in the dune-ridge forest ${ }^{3}$, and the surrounding parkland habitat. ${ }^{5}$ Known to forage opportunistically ${ }^{6}$, Baltimore Orioles fed on the post-egg stages of the tent caterpillar and fed them to their young ${ }^{4}$, despite a diet in the ridge forest that otherwise consisted predominantly of midges and other dipterans. ${ }^{7,8}$ Elsewhere, Baltimore Orioles had been determined to take predominantly lepidopteran larvae and pupae ${ }^{6,9}$, including the Forest Tent Caterpillar. ${ }^{10}$

Observations in upstate New York had previously revealed a functional response ${ }^{11}$ by Baltimore Orioles to an outbreak of this tent caterpillar. Orioles "... not only devoured [tent caterpillar] larvae and pupae, and moths, but wholly cleared many trees of the pupae, ripping the cocoons so fast that the young were given hundreds of pupae per day." 12 However, despite the superabundant food supply to which the orioles responded, there was apparently no increase in the number of nesting pairs. ${ }^{12}$ Similarly, the closely related Bullock's Oriole (I. bullockii) was recorded taking larvae of another species of tent caterpillar, in California, but the nesting density did not increase during the four years of that study. The conclusion was that this species is not particularly attracted to areas of local tent caterpillar abundance. $^{13}$

At Delta Marsh, Baltimore Orioles not only preyed on Forest Tent Caterpillars that suddenly became available in the ridge forest, the nesting density doubled the following year, then declined a year later when tent caterpillars were no longer present. ${ }^{3}$ These changes in nesting density were interpreted as a numerical response to the presence of this new and abundant prey. ${ }^{3}$ Strengthening support for this hypothesis would be whether a similarly sudden increase in nesting density was recorded during a subsequent tent caterpillar outbreak in the ridge forest, or, without one, if no abrupt increase in nesting density occurred in the absence of tent caterpillars. To test this hypothesis, I recorded nesting densities in this population through 1995 , by which time erosion of the north side of the dune-ridge forest was altering the habitat. In addition, I compared these densities to the regional trend in densities using data derived from the Breeding Bird Survey. ${ }^{14}$

Baltimore Orioles were not the only species that responded to the sudden availability of prey in the ridge forest in 1976 and 1977.
Observations summarized below show the nomadic Black-billed Cuckoo (Coccyzus erythropthalmus) nested in both years of the outbreak, laying eggs exceptionally early; a small population of Bay-breasted Warblers (Setophaga castanea) nested for the first and only time in 1976; and a pair of Evening Grosbeaks (Coccothraustes vespertinus) fed on caterpillar pupae in 1976 , its only appearance during the breeding season.

\section{Study area and Methods}

Research in the ridge forest spanned 1973 to 2010. Baltimore Orioles were studied in a 1.2-km (10 ha) portion of the forested dune ridge that stretched westward from the Assiniboine River Diversion (50 11 N, $98^{\circ} 19 \mathrm{~W}$; Figure 1$)^{15,16}$, a diked waterway that carries water from the Assiniboine River north to Lake Manitoba during springs when run-off water is excessive. This stretch of narrow riparian habitat was situated on the properties of the Delta Marsh Field Station (University of Manitoba) and, immediately to the west, Portage Country Club.

The vegetation of the ridge forest is an early successional stage of the Aspen-Oak Section of the Boreal Forest Region, which was dominated by flood-resistant species ${ }^{16}$ : Peachleaved Willow (Salix amygdaloides), Manitoba Maple (Acer negundo), and Green Ash (Fraxinus pennsylvanica). Eastern Poplar (Populus deltoides) occurred intermittently and American Elm (Ulmus americana) was rare. Common shrubs included Sandbar Willow (S. interior), Red-berried Elder (Sambucus pubens), Red-osier Dogwood (Cornus stolinifera), Choke 
Cherry (Prunus virginiana), and Pin Cherry (P. pensylvanica). Manitoba Maple was the most abundant tree species in the dune-ridge forest, followed by Peach-leaved Willow and Green Ash, plus Sandbar Willow, all of which are adapted to different soil conditions, which result in considerable heterogeneity of the vegetation within this forest. ${ }^{16}$

I banded and colour-marked Baltimore Orioles in 1974 and 1975 in preparation for initiation of the study in $1976 .{ }^{3}$ I determined nesting density by counting nests each autumn from 1976 to 1995 on 1-3 days between October 27 and November 3, by which time most leaves had dropped and nests were visible (Figure 2). The neatly woven, pensile nests were attached strongly to the supporting branches, from which they hung 17,18, and were generally placed high in the canopy ${ }^{4}$, frequently out of my reach. Recording these nests was an accurate index of the breeding population each year. Of 78 nests at which I determined clutch size from 1976-19783, all but one nest (98.7\%) persisted until leaf-fall; the missing nest and the others were included in the annual totals of nests. Persistence of nests has been reported elsewhere between $50 \%$ and $66 \%$, albeit those nests had overwintered. ${ }^{19}$ Only three cases of replacement nesting and no second broods were recorded. In 1976, a pair that deserted a nest after only a few strands of nest material had been assembled reared a brood in a new nest constructed nearby.

I counted nests by walking back and forth along the north and south sides of the ridge forest and down the middle along its length, recording each nest and the species of tree in which it was constructed. Nests were not counted after 1995 because the ridge and characteristics of the habitat had begun to change. Sandbar Willow was dying along both edges of the ridge forest and erosion was starting to eat away at the north (lake) side due to storm-driven, excessively high water levels of Lake Manitoba that were being maintained to control flooding. ${ }^{20}$ Further degradation of the dune ridge and riparian forest

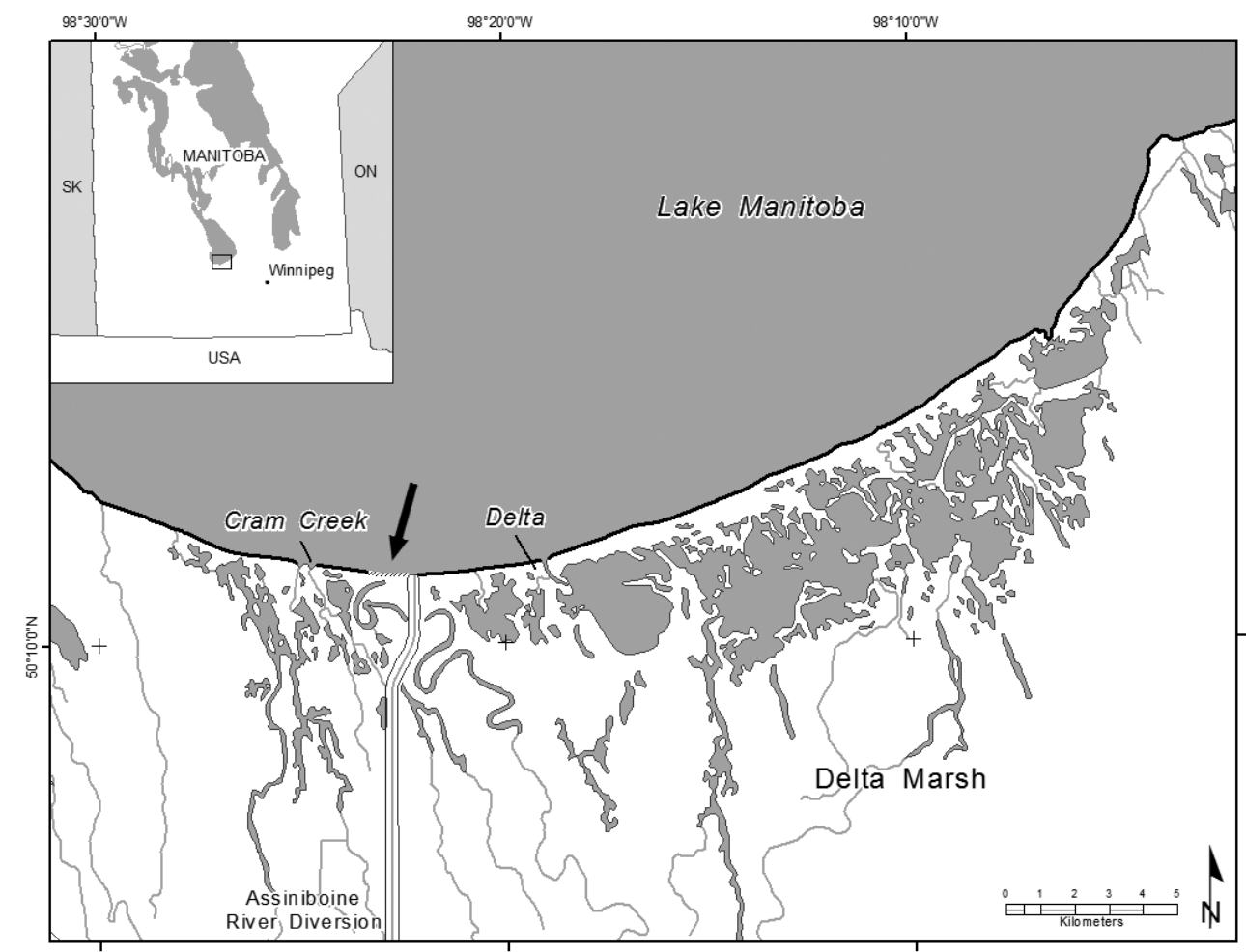

FIGURE 1. Map of Delta Marsh, Manitoba, showing the narrow dune-ridge forest (black line) and 1.2-km (10 ha) portion of the ridge (indicated by arrow) in which Baltimore Oriole nests were surveyed. Map prepared by Mapmonsters GIS. occurred during a particularly destructive storm in the spring of 2011, which forced water and ice into the ridge forest, and prolonged flooding along the south side of the dune ridge. ${ }^{21}$

\section{Results}

The presence of Forest Tent Caterpillar in the ridge forest was part of a broader outbreak across portions of the Canadian Prairie Provinces, which was recorded initially in $1971^{5}$, although larvae were not detected in the ridge forest until 1976. According to the known life stages outlined for this insect ${ }^{5}$, adult moths dispersed in summer and laid eggs in the ridge habitat the previous year. Eggs hatched in 1976 and the first larvae were sampled in regular sweep-netting of tree foliage in mid-May, peaking by mid-June. ${ }^{3,22,23}$ Caterpillars emerged about one week earlier in 1977 but generally had died by mid-June. Tent caterpillars were not detected in regular sweep-net sampling and visual searches through $1985^{8,24}$, or during visual searches conducted thereafter.

The first three years of nest counts (1976-1978) encompassed the outbreak of Forest Tent Caterpillar in the ridge forest. The nesting density doubled from 5.4 nests/ha in 1976 to $10.5 /$ ha in 1977 , but declined to $5.3 /$ ha in 1978 , essentially the level recorded in 1976. Densities were similar through 1980, but declined again, in tandem with the regional population, before increasing to (1.8 nests/ha) in 1985 and 2.6/ha in 1992 (Figure 3, Appendix 1).

The number of nests from which at least one young fledged was $94.7 \%$ in 1976 ( $n=36$ nests), 84.4\% in 1977 ( $n$ $=38)$, and $88.2 \%$ in $1978(n=15){ }^{3}$ Analyzed previously ${ }^{3}$, mean brood size at fledging in 1976 (4.9 young/ successful nest; $n=17$ nests) and in 1978 (4.8 young; $n=12$ ) did not differ significantly. Mean brood size in 1976 was significantly larger than 


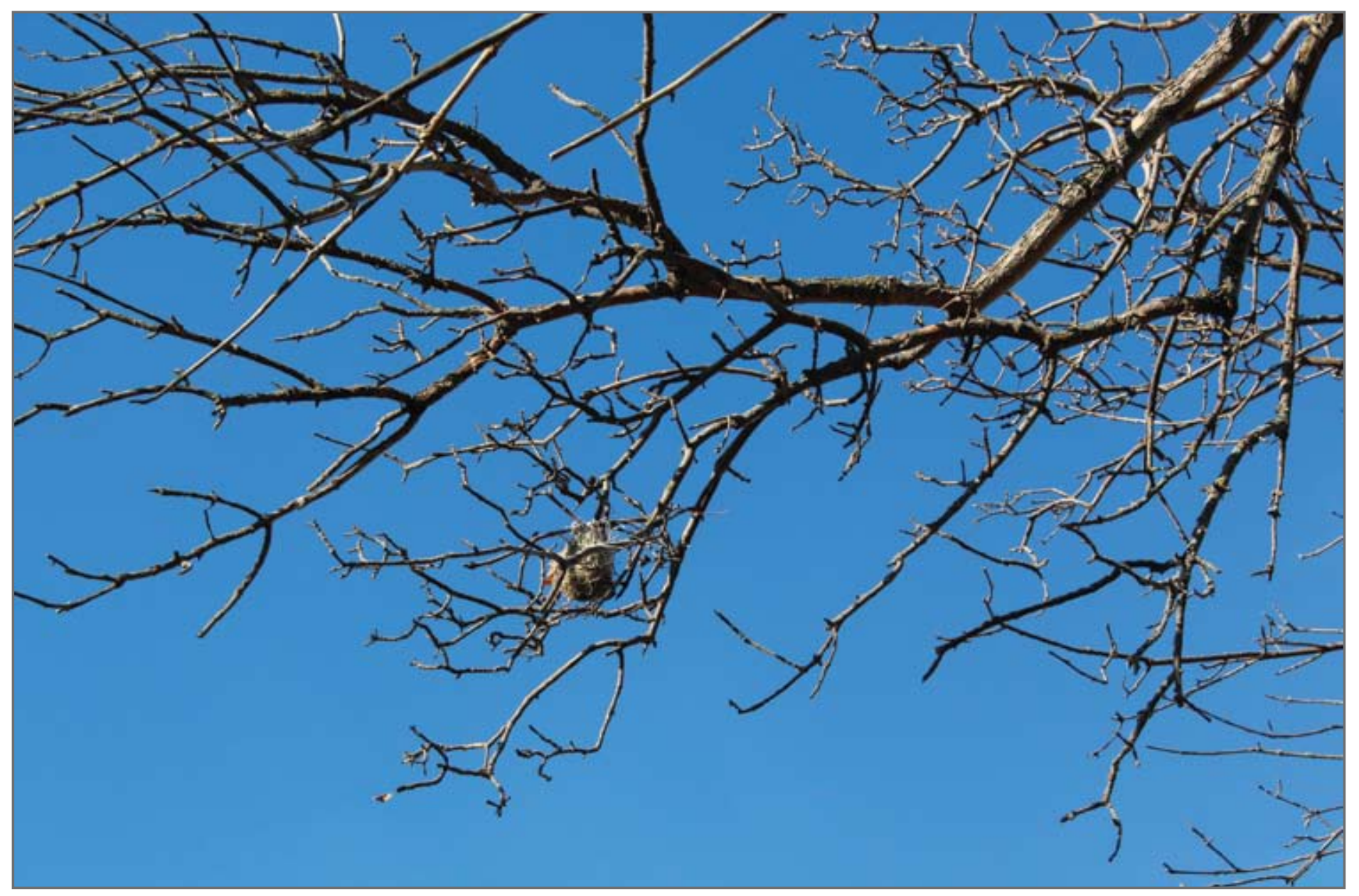

FIGURE 2. Pensile nest of the Baltimore Oriole, this one suspended in a Green Ash (Fraxinus pennsy/vanica). The nest became visible after leaf-fall in the autumn. Photo credit: S.G. Sealy

in 1977 (3.8; $n=37)$. Mean brood size was significantly larger in 1976 than in $1977(3.8 ; n=37)$. Sample sizes I used to calculate nest success were greater than those for mean brood size because fledging of at least one young was recorded at some inaccessible nests where brood size was not determined. ${ }^{3}$

\section{Discussion}

Changes in nesting density of Baltimore Orioles

The dramatic changes in density of nesting Baltimore Orioles (Figure 3 ) in the early years of this study apparently reflected responses to the sudden availability of an abundant but short-lived food source, and were not a coincidence. That similar increases were not recorded in subsequent years in the absence of tent caterpillars supports this hypothesis. Had another caterpillar outbreak occurred, to which
Baltimore Orioles responded with an increase in numbers, even stronger support for the hypothesis would have been recorded. Following the increase in the number of nests in 1977, the density returned to the level recorded in 1976 and remained there for three years before declining further, generally in tandem with the provincial population (Figure 3). The orioles' responses to this prey may have promoted the short-term recovery of the population in the ridge forest, before the population succumbed to regional/continental factors affecting declines of the species on a broader scale. This is conjecture, however, without knowledge of the orioles' nesting density in the ridge forest prior to the outbreak of tent caterpillars in the mid-1970s. ${ }^{2}$

The greater number of nesting pairs in 1977 was augmented by unbanded males and females. These individuals probably included secondyear males ${ }^{3,26}$, which originated from populations outside the ridge forest or from elsewhere in this habitat, or, individuals that were present but not banded in 1976 may have returned the following year, as fidelity to a previous breeding site is well developed in Baltimore Orioles. ${ }^{3,6}$ The increase was not due to the return of young produced in the ridge forest in 1976. Nestling Baltimore Orioles exhibit weak fidelity to their natal site (birthplace), as recaptures of banded nestlings and fledglings have confirmed in Massachusetts (zero of 51 nestlings returned ${ }^{20}$ ) and in the dune-ridge forest (of 512 banded in 1976, 17 [3.3\%] were recorded in 1977; of 339 banded in 1977, two were recorded [0.6\%] in 1978).

Data posted by the Breeding Bird Survey for the Baltimore Oriole ${ }^{14,27}$ also revealed an increase from 1976- 


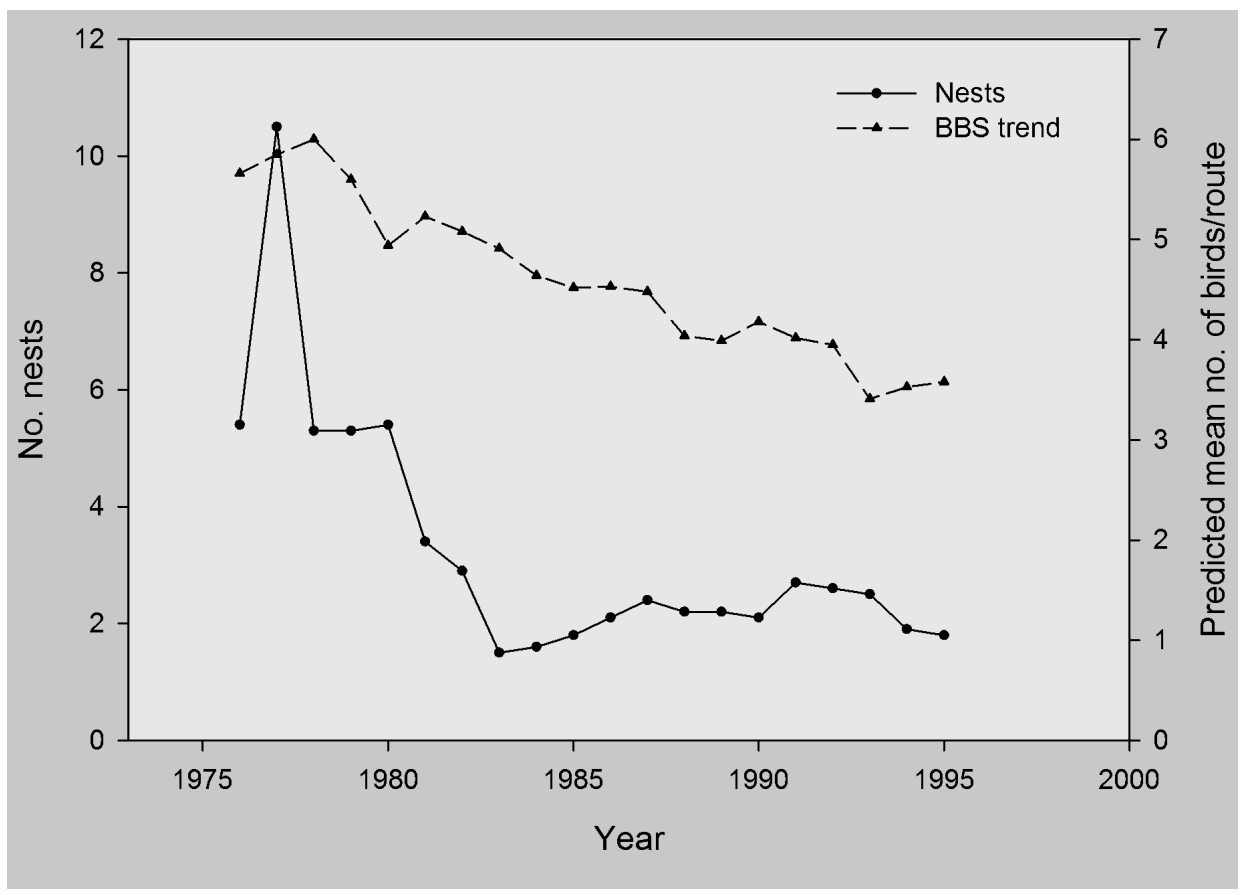

FIGURE 3. Abundance of Baltimore Orioles (nests/ha) in the dune-ridge forest, Delta Marsh and in Manitoba (BBS trend), 1976-1995.

78 (Figure 3). I interpreted this as a response to short-term availability of superabundant prey. ${ }^{3}$ This increase was generally followed by a decline over the next 15 years in the absence of tent caterpillars, with no subsequent short-term increases in nesting density, which further supports the hypothesis. Responses to the new prey source may have enhanced the oriole's short-term recovery or maintenance at the local scale, before eventually succumbing to regional or continental stressors.

\section{Other species' responses to tent} caterpillars in the ridge forest

Evidence suggests strongly that Baltimore Orioles responded reproductively to the presence of Forest Tent Caterpillars in the ridge forest in 1976-77, by feeding themselves and their young on caterpillars and by increasing their numbers. Three additional species also apparently responded to this sudden availability of prey: Black-billed Cuckoo $^{28}$, Bay-breasted Warbler ${ }^{23}$, and Evening Grosbeak ${ }^{29}$.

Not only did more Black-billed Cuckoos lay larger "clutches" in
1976 and 1977, they initiated them earlier than in years when the caterpillars were absent, if they nested at all. ${ }^{28,30}$ The large clutches were later determined likely to have been products of conspecific brood parasitism ${ }^{30}$ - in this case, one cuckoo laying in another cuckoo's nest - a reproductive strategy that has been documented previously in the genus Coccyzus during similar outbreaks of superabundant prey. ${ }^{31}$

The migratory Bay-breasted Warbler nested in the ridge forest for the first and last time in $1976^{23}$, although this species stopped over irregularly in spring in subsequent years. Larval caterpillars were present in the ridge forest when the first individuals arrived in $1976 .{ }^{23}$ Six active nests were recorded and adults fed on recently hatched, clustered tent caterpillars, although their diet was supplemented with other insects normally available at this site. ${ }^{23}$ Bay-breasted Warblers are known to track prey in spring, which results in variable numbers settling locally during the breeding season, particularly in response to outbreaks of spruce budworms (Choristoneura and Acleris). ${ }^{32,33}$ Predation recorded on Forest Tent Caterpillars by Baybreasted Warblers added another species to the list of predators on this insect. $^{10}$

A pair of Evening Grosbeaks fed on pupae in a defoliated Manitoba Maple on June 18, 1976, the only year this species was recorded in the ridge forest during the breeding season. ${ }^{29}$ Both birds consumed at least two pupae during 15 minutes of observation, but they left the area and were not observed again. Evening Grosbeaks are known to respond to outbreaks of Spruce Budworm (Choristoneura fumerifana Clem.) and other larvae ${ }^{34}$, but predation on Forest Tent Caterpillar documented here added another species to the list of predators. ${ }^{10}$ This was the species' only recorded occurrence in the ridge forest during the breeding season during nearly 40 years of work in this habitat.

Regardless of the Evening Grosbeak's propensity to move widely in search of prey ${ }^{34}$, the appearance of one pair in the ridge forest in 1976 certainly did not confirm that its presence was in response to tent caterpillars, or that it was a coincidence. ${ }^{29}$ Other pairs of Evening Grosbeaks may have gone undetected, although we worked intensely over more than $20 \mathrm{~km}$ of the ridge forest without additional observations.

\section{Summary}

Results of several studies revealed that songbirds nesting in the ridge forest preyed predominately on emergences of adult midges, which were generally at levels of superabundance. ${ }^{8,22,36}$ Between successive emergences, when midges were less abundant, most species preyed on a broader range of taxa until the next hatch occurred, usually within a few days. ${ }^{8}$ Tent caterpillars provided food on top of that available through exploitation of the midges, thus, augmenting the reproductive effort of several species. Despite that midges provided the usual abundant 
food in 1976 and 19778,22, Baltimore Orioles responded to this new prey source and apparently enhanced their short-term maintenance at the local scale, before succumbing to conditions experienced more broadly in the region.

\section{Acknowledgements}

I am indebted to personnel of the former Delta Marsh Field Station (University of Manitoba) for accommodation and in-kind support, and to many students and other co-workers who assisted with field work, including banding. The board of the Portage Country Club granted permission to conduct some of this work on their property. I thank Todd J. Underwood for comments on an early draft of the manuscript and Stephen K. Davis for assistance with later drafts. An anonymous reviewer offered constructive comments on the final draft of the manuscript. Baltimore Orioles were banded under permits issued by the Canadian Wildlife Service (Environment Canada). The map was prepared by Mapmonsters GIS, Victoria, British Columbia, with assistance from Nikola Zukanovic.
This work was funded chiefly by the Natural Sciences and Engineering Research Council of Canada, with ancillary funding provided by the Canadian National Sportsmen's Show, Manitoba Conservation (Wildlife Branch), and University of Manitoba Research Grants Program.

1. Thompson ET (1891) The birds of Manitoba. Proceedings of the United States National Museum 13:457-643.

2. Hochbaum PW (1971) The Delta Marsh. Conservation Extension Branch, Manitoba Department of Mines, Resources and Environmental Management, Winnipeg.

3. Sealy SG (1980) Reproductive responses of Northern Orioles to a changing food supply. Canadian Journal of Zoology 58:221-227.

4. MacKenzie DI, Sealy SG, Sutherland DG (1982) Nest site characteristics of the avian community in the dune ridge forest, Delta Marsh, Manitoba: A multivariate analysis. Canadian Journal of Zoology 60:22122223.

5. Hildahl V, Campbell AE (1975) Forest Tent Caterpillar in the Prairie Provinces. Northern Forest Research Centre, Edmonton, Information Report NOR-X-185.

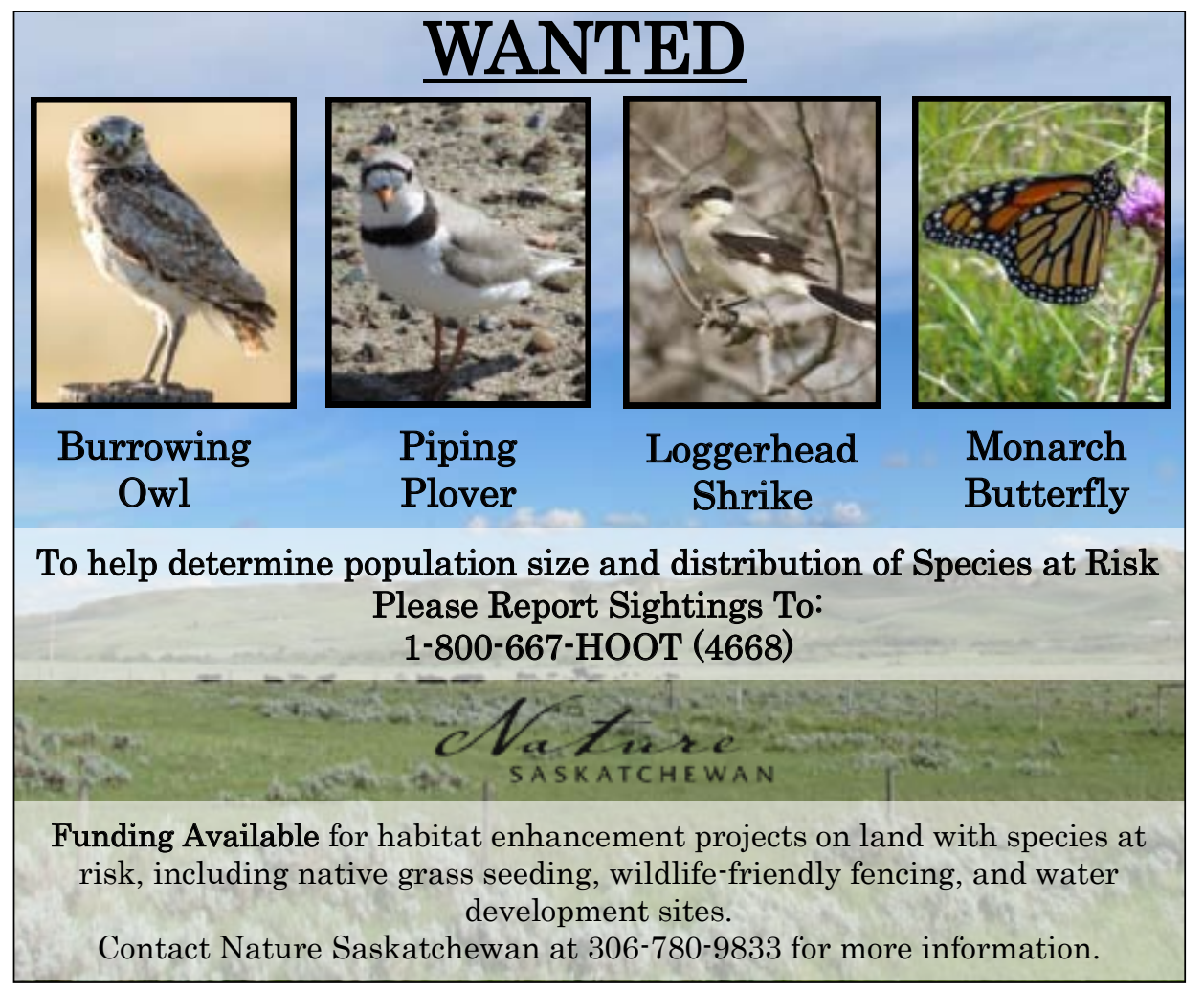


18. Schaefer VH (1976) Geographic variation in the placement and structure of oriole nests. Condor 78:443-448.

19. Pank LF (1974) Nesting biology of the Baltimore Oriole. M.S. thesis, University of Massachusetts, Amherst.

20. Anonymous (1974) Flood control. Manitoba Department of Mines, Resources, and Environmental Management, Water Resources Division, Winnipeg, MB.

21. Hobson KA, Norris DR, Goldsborough G, Sealy SG (2012) Requiem for a field station: The loss of a Canadian ornithological treasure. Avian Conservation and Ecology 7(2):7.http:// dx.doi.org/10.5751/ACE-00553-070207.

22. Busby DG, Sealy SG (1979) Feeding ecology of a population of nesting Yellow Warblers. Canadian Journal of Zoology 57:1670-1681.

23. Sealy SG (1979) Extralimital nesting of Bay-breasted Warblers: Responses to forest tent caterpillars? Auk 96:600-603.

24. Biermann GC, Sealy SG (1982) Parental feeding of nestling Yellow Warblers in relation to brood size and prey availability. Auk 99:332-341.

26. Sealy SG (1979) Prebasic molt of the Northern Oriole. Canadian Journal of Zoology 57:1473-1478.

27. North American Breeding Bird Trend Results, accessed May 15, 2018 www. mbr-pwrc.usgs.gov/cgi-bin/atlasa15.pl?05 070\&1\&15\&csrfmiddlewaretoken=3YKak k7LxT2ki6NSpl4mstudYCqdW02C

28. Sealy SG (1978) Possible influence of food on egg laying and clutch size in the Black billed Cuckoo. Condor 80:103-104.

29. Sealy SG Evening grosbeaks feeding on pupae of the Forest Tent Caterpillar in the dune-ridge forest, Delta Marsh, Manitoba, spring 1976. Blue Jay 76(1):2425.

30. Sealy SG (2003) Laying times and a case of conspecific nest parasitism in the Black-billed Cuckoo. Journal of Field Ornithology 74:257-260.

31. Nolan V, Jr, Thompson CF (1975) The occurrence and significance of anomalous reproductive activities in two North American nonparasitic cuckoos Coccyzus spp. Ibis 117:496-503.

\begin{tabular}{|r|r|r|}
\hline 1976 & 52 & 5.4 \\
\hline 1977 & 101 & 10.5 \\
\hline 1978 & 51 & 5.3 \\
\hline 1979 & 51 & 5.3 \\
\hline 1980 & 52 & 5.4 \\
1981 & 33 & 3.4 \\
\hline 1982 & 28 & 2.9 \\
\hline 1983 & 14 & 1.5 \\
\hline 1984 & 15 & 1.6 \\
\hline 1985 & 17 & 1.8 \\
\hline 1986 & 20 & 2.1 \\
\hline 1987 & 23 & 2.4 \\
\hline 1988 & 21 & 2.2 \\
\hline 1989 & 21 & 2.2 \\
\hline 1990 & 20 & 2.1 \\
\hline 1991 & 26 & 2.7 \\
\hline 1992 & 25 & 2.6 \\
\hline 1993 & 24 & 2.5 \\
\hline 1994 & 18 & 1.9 \\
\hline 1995 & 17 & 1.8 \\
\hline
\end{tabular}

APPENDIX 1: Density of Baltimore Oriole nests (number nests/ha) in a $1.2-\mathrm{km}$ (10 ha) portion of the forested dune ridge, Delta Marsh, Manitoba, 1976-1995.

32. Morse DH (1978) Populations of Baybreasted and Cape May warblers during an outbreak of the spruce budworm. Wilson Bulletin 90:404-413.

33. Gage SH, Miller CA, Mook MJ (1970) The feeding response of some forest birds to the Black-headed Budworm. Canadian Journal of Zoology 48:359-366.

34. Venier LA, Pearce JL, Fillman DR, McNicol DK, Welsh DA (2009) Effects of Spruce Budworm (Choristoneura fumiferana (Clem.)) outbreaks on boreal mixed-wood bird communities. Avian Conservation and Ecology - Écologie et conservation des oiseaux 4(1):3. [online] URL: http:// www.ace-eco.org/vol4/iss1/art3/

35. Guinan DM, Sealy SG (1987) Diet of House Wrens (Troglodytes aedon) and the abundance of the invertebrate prey in the dune ridge forest, Delta Marsh, Manitoba. Canadian Journal of Zoology 65:15871596.
2018 GRADUATE
SCHOLARSHIP WINNER

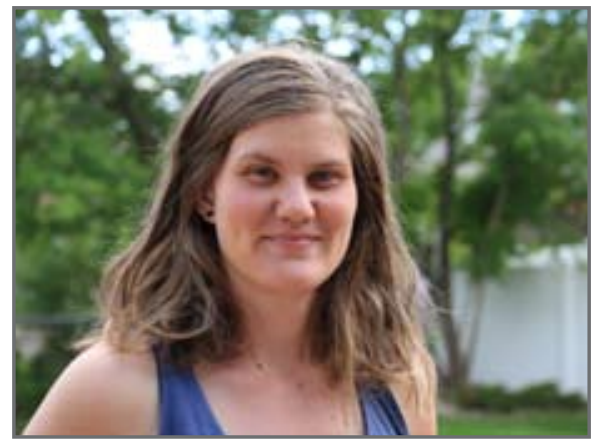

The Margaret Skeel Graduate Student Scholarship was established by Nature Saskatchewan to stimulate research of all aspects of the natural world and human relation with nature, and to promote conservation and sustainable use of natural resources. The $\$ 2,000$ scholarship is awarded annually to assist a graduate student attending a post-secondary institution in Saskatchewan.

The 2018 scholarship recipient is Katie Doke Sawatzky, who is a master's of journalism student at the University of Regina. She is tackling the public debate surrounding prairie grasslands use and preservation. In the past decade, the province has sold 1.1 million acres of Crown land in the prairie ecoregion, while Ottawa has closed the Community Pasture Program. Katie will travel throughout Saskatchewan to document the views of ranchers, mixed farmers, hunters, pasture patrons, new leaseholders, naturalists and government officials. She will also delve into the economics and scientific aspects of grasslands, and chart changes to the ecosystem since settlement. The results of her investigation will be published on a multimedia website that incorporates articles, videos, audio podcasts, and infographics. The purpose of the project is to provide a place where diverse perspectives on native prairie can be seen alongside one another in order to raise the public's awareness of this endangered ecosystem and to create understanding between interested groups. 